\title{
Biochar Effect on Cadmium Accumulation and Phytoremediation Factors by Lavender (Lavandula stoechas L.)
}

\author{
Seyyed Behrad Hashemi ${ }^{1}$, Mohammadreza Momayezi ${ }^{*}$, Daryoush Taleei ${ }^{2}$ \\ ${ }^{1}$ Innovative Technologies in Functional Food Production Research Center, Varamin-Pishva Branch, Islamic Azad University, \\ Tehran, Iran \\ ${ }^{2}$ Medicinal Plants Research Center, Shahed University, Tehran, Iran \\ Email: *momayeziir@gmail.com
}

How to cite this paper: Hashemi, S.B. Momayezi, M. and Taleei, D. (2017) Biochar Effect on Cadmium Accumulation and Phytoremediation Factors by Lavender ( $\mathrm{La}$ vandula stoechas L.). Open Journal of Eco$\log y, 7,447-459$.

https://doi.org/10.4236/oje.2017.77031

Received: May 5, 2017

Accepted: July 7, 2017

Published: July 10, 2017

Copyright () 2017 by authors and Scientific Research Publishing Inc. This work is licensed under the Creative Commons Attribution International License (CC BY 4.0)

http://creativecommons.org/licenses/by/4.0/

\begin{abstract}
The contaminated soil has become a global problem for agricultural and environmental scientists. The soil as a natural resource is polluted by cadmium as a heavy metals from the different sources such as phosphorus fertilizers. The aim of this study was to investigate the biochar effect on absorption factor (AF) and translocation factor (TF) as the phytoremediation factors at different cadmium concentrations by lavender plant. The experiment was conducted in $3 \times 4$ factorial design including biochar treatment at the volumetric percentage ratio of $0 \%, 20 \%$ and $40 \% \mathrm{v} / \mathrm{v}$ and cadmium treatment at $0,50,100$ and $150 \mathrm{mg} \mathrm{Cd} \cdot \mathrm{kg}^{-1}$ soil under greenhouse condition. The data analysis indicated that the biochar and cadmium treatments significantly $(\mathrm{p} \leq 0.05)$ affected the plant dry biomass. The biochar addition caused to decrease the cadmium content of the root tissue. Biochar decreased cadmium uptake by lavender plant and also cadmium was accumulated by the root tissue and was prevented to translocate cadmium into the shoot tissue. Increasing cadmium concentration in soil caused an increase in cadmium adsorption factor however there was a significant decrease for translocation factor. It can be concluded to consider the possibility of planting the lavender with biochar application to amend the cadmium contaminated soils.
\end{abstract}

\section{Keywords}

Biochar, Cadmium Contaminated Soil, Phytoremediation, Lavender, Translocation Factor, Absorption Factor

\section{Introduction}

The aromatic plants as providing several medicine productions are one of the 
most important plants which have been considered for phytoremediation as well as the accumulator plants. Phytoremediation is used for removing the contaminated material such as cadmium from the water and soil by plants. Reducing the risks of the pollutants such as heavy metals, trace elements, organic compounds and radioactive materials is concerned to the environmental problems. The heavy metals are contaminants which accumulated in soil, water and plants. The soil after the air and water is the major component of the environment where the contaminants are not easily measurable and traceable [1].

Cadmium is considered one of the major contaminants in environment and its general amount is increasing in soil and water by using phosphorus fertilizers and wastewater especially in semi-arid and arid regions. Thereby its removal from soil is receiving wide attention because of the discharge of that contaminant is evidenced in the growth of plants and crops. The cadmium accumulation in crop tissues and its introduction in the food chain are harmful for human health and animal life [2]. There are some technologies for remediating of heavy metals from contaminated soils. Phytoremediation is considered as an environmental friendly, cost-effective and inventive method to decrease heavy metals risk in soils [2] [3] [4]. Lavender (Lavandula stoechas L.) is an aromatic plant and can grow in contaminated soils without any decreasing in its final product. The final product will be free from heavy metals [2].

Biochar as a production from the biomass pyrolysis has been applied for a wide range. Biochar as a stable, recalcitrant organic carbon compound has the potential to increase soil fertility and then reduce nutrient leaching [5]. Its physicochemical properties related to porous structure and active adsorbing surface cause to decrease the release of heavy metals, thereby improving crop growth [6].

The objective of this study is to evaluate the biochar effect on cadmium uptake from contaminated soils by lavender plant and to assess cadmium accumulation in different lavender tissues.

\section{Materials and Methods}

This study was carried out in the national institute research of medicinal and aromatic plants at Shahed University, Tehran, Iran under greenhouse condition in 2015. The average basic soil physicochemical properties were summarized in Table 1 .

Two factors factorial design was laid out in completely randomized design (CRD) with three replications. The treatments were cadmium concentration at four levels including 0, 50, 100 and $150 \mathrm{mg} \mathrm{Cd} \cdot \mathrm{kg}^{-1}$ soil from the cadmium sulfate $\left(\mathrm{CdSO}_{4}\right.$, Merck Germany) and biochar from almond wood chips pyrolysis at

Table 1. The basic soil characteristics.

\begin{tabular}{cccccccccccc}
\hline $\mathrm{PH}$ & $\begin{array}{c}\mathrm{EC} \\
\mathrm{dS} \cdot \mathrm{m}^{-1}\end{array}$ & $\begin{array}{c}\mathrm{CEC} \\
\mathrm{me} \cdot 100 \mathrm{~g}^{-1} \text { soil }\end{array}$ & $\begin{array}{c}\text { Organic } \\
\text { matter } \%\end{array}$ & $\begin{array}{c}\text { Soil } \\
\text { texture }\end{array}$ & $\begin{array}{c}\text { Clay } \\
\%\end{array}$ & $\begin{array}{c}\text { Sand } \\
\%\end{array}$ & $\begin{array}{c}\text { Silt } \\
\%\end{array}$ & $\begin{array}{c}\text { Sodium } \\
\text { me. } \mathrm{l}^{-1}\end{array}$ & $\begin{array}{c}\text { Calcium } \\
\text { me } \cdot \mathrm{l}^{-1}\end{array}$ & $\begin{array}{c}\text { Potassium } \\
\text { me } \cdot \mathrm{l}^{-1}\end{array}$ & $\begin{array}{c}\text { Magnesium } \\
\mathrm{me} \cdot \mathrm{l}^{-1}\end{array}$ \\
\hline 7.4 & 2.48 & 13.4 & 1.17 & Loamy & 10 & 49.4 & 40.6 & 1.7 & 46 & 1.72 & 4.17 \\
\hline
\end{tabular}


three volumetric ratio including 0,20 and $40 \mathrm{v} / \mathrm{v}$ ratio. The almond wood chips as feedstock were pyrolyzed at the highest heating temperature (HHT), $350^{\circ} \mathrm{C}$. Full control of the heating rate was not possible, but temperature changes and mean heating rates were monitored. The particle size less than $4 \mathrm{~mm}$ was the most common in the biochar used in this study. The soil without biochar and cadmium addition was identified as the control.

Three lavender seedlings were planted in $10-\mathrm{kg}$ pot which is filled up by treated soils. One seedling was selected in each pot after 10 days from the planting time. The soil moisture was kept at field capacity by tap water. Air temperature ranged from $30^{\circ} \mathrm{C}$ to $19^{\circ} \mathrm{C}$ during the day and night, respectively.

The seedlings shoot and root tissues were separately sampled after six months. The fresh samples of shoot and root tissues were dried by oven at $70^{\circ} \mathrm{C} \pm 5^{\circ} \mathrm{C}$ for 48 hours to measure their dry weight. The cadmium concentration of root and shoot tissues were measured according to the wet digestion method of Boline and Schrenk 1976 [7]. The samples were homogenized by $4 \mathrm{~N} \mathrm{HNO}_{3}$ and heated until $80^{\circ} \mathrm{C}$ for 2 hours. The concentration of cadmium in the digested solution was determined by AAnalyst 700, Atomic Absorption Spectrometry (AAS), PerkinElmer, USA.

The absorption factor (AF) and translocation factor (TF) were calculated to determine cadmium accumulation in the soil and the different lavender tissues [8]. Absorption factor, the ratio of cadmium concentration in the lavender root tissue to that in the soil (Formula (1)) and translocation factor, the ratio of cadmium concentration in the lavender root tissue to that in the shoot tissue (Formula (2)) were computed as:

$$
\begin{gathered}
A F=\frac{C_{\text {Root }}}{C_{\text {Soil }}} \\
T F=\frac{C_{\text {Shoot }}}{C_{\text {Root }}}
\end{gathered}
$$

where $\mathrm{C}_{\text {Soil,RootandShoot }}$ are cadmium concentration in the soil, root and shoot tissues (mg.Cd $\cdot \mathrm{kg}^{-1}$ soil), respectively.

Data analysis was performed using two-way analysis of variance (PROC GLM of SAS, SAS Institute, Cary, NC, USA). Differences between individual means were identified using Duncan test at the $5 \%$ significance level.

\section{Results and Discussion}

The data analysis showed that the simple effects of biochar treatments on all the parameters with the exception of translocation factor (TF) were significant ( $\mathrm{p} \leq$ 0.01 ). At the same result, all of the measured parameters were significantly affected by the cadmium treatments. The interaction effects between biochar application and cadmium concentration were only non-significant for translocation factor (TF).

There was significant difference between the root and shoot dry biomass when the biochar and cadmium treatments were applied. As shown in Figure 1(a) and 
Figure 1(b), the plant dry biomass both the root and the shoot increased from control media (16.5 and $5.55 \mathrm{mg}$ for shoot and root dry biomass, respectively) up to the highest biochar treatment $(20.1$ and $6.27 \mathrm{mg}$ for shoot and root dry biomass, respectively). However, a significant difference was not found between control and $20 \mathrm{v} / \mathrm{v}$ ratio of biochar application (Figure 1 (a)).

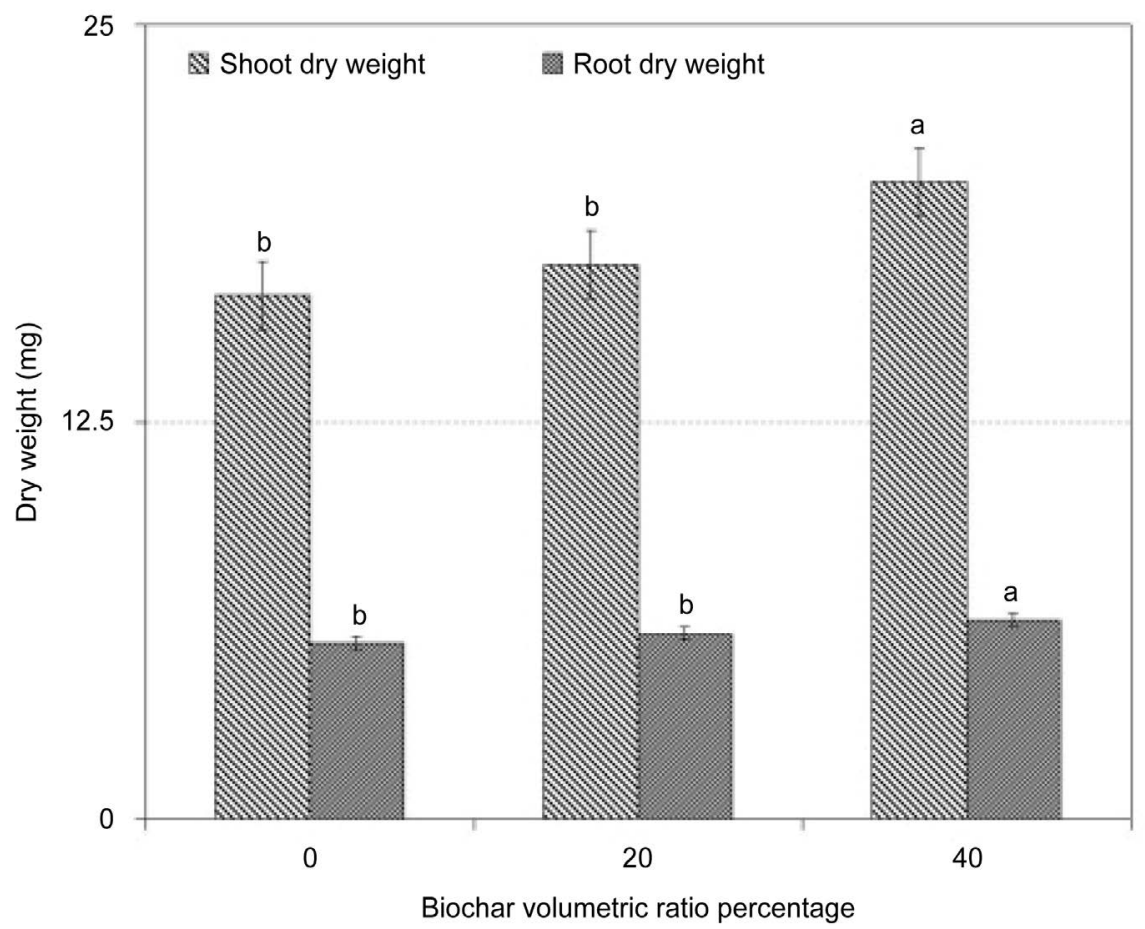

(a)

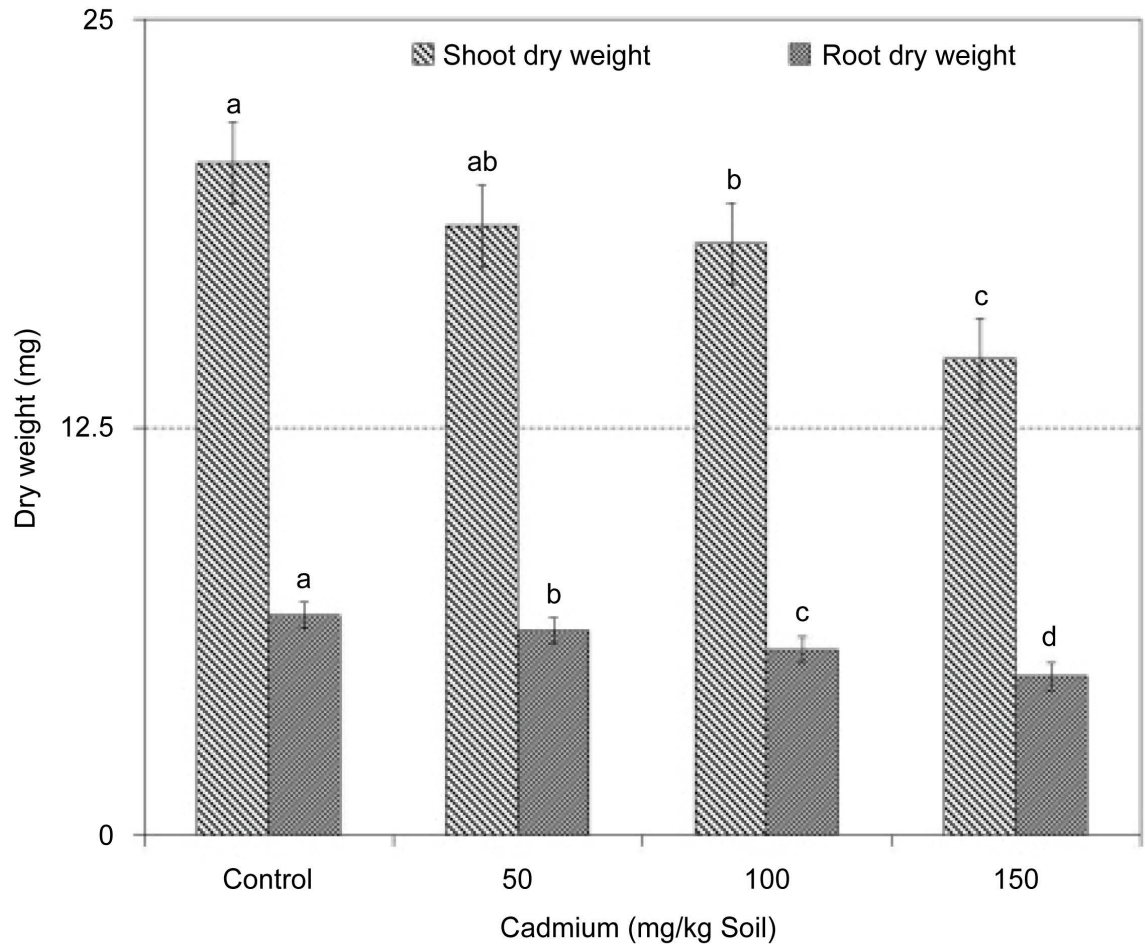

(b) 


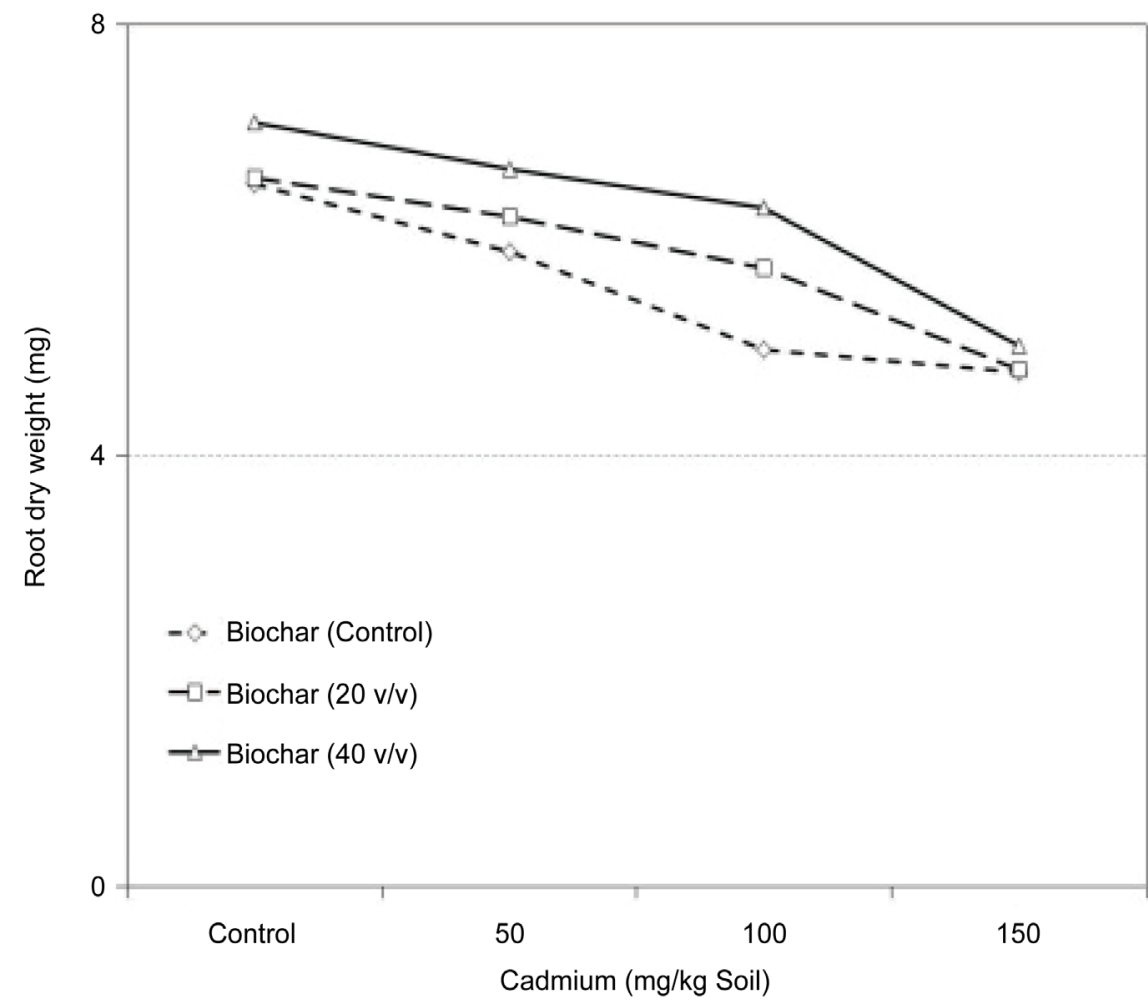

(c)

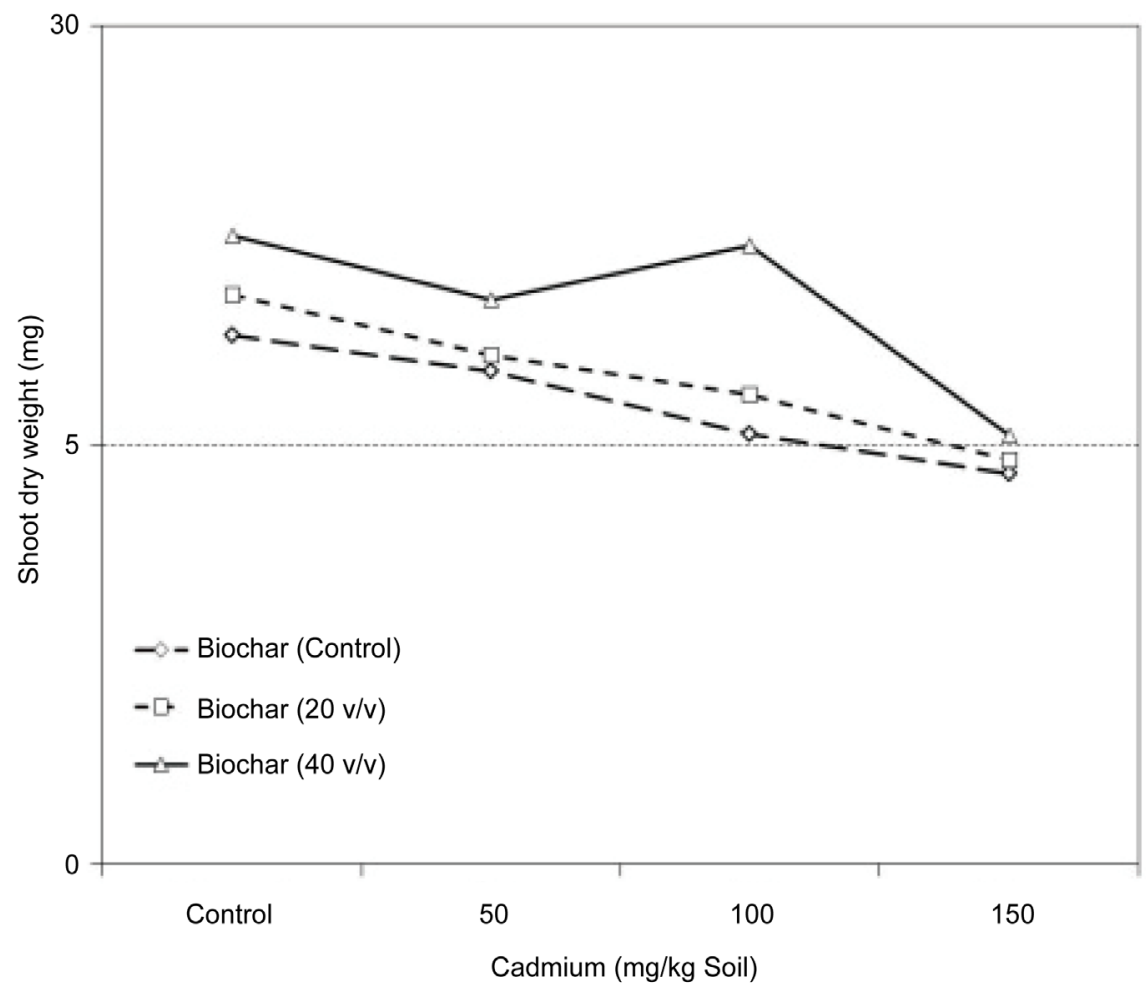

(d)

Figure 1. Effects of biochar (control, 20 and $40 \mathrm{v} / \mathrm{v}$ ) and cadmium concentration (control, 50, 100 and $150 \mathrm{mg} \mathrm{Cd} \cdot \mathrm{kg}^{-1}$ soil) on the lavender root and shoot dry biomass. The simple and the interaction effects are presented by $a, b, c$ and $d$, respectively. Means \pm standard error (S.E.) is shown in error bars $(\mathrm{p} \leq 0.05)$. 
The results released that there was a significant decrease in the dry biomass including the root and the shoot when the cadmium concentration from control to the highest concentration of cadmium in soil, hereby the cadmium had a toxic effect on the lavender growth (Figure 1(b)). The results emphasized the toxic and the restrictive effect of the cadmium concentration of soil on the root growth [9]. On the other hand, the positive effect of biochar addition on the root and the shoot dry biomass can be observed from Figure 1(a). It was reported that the soil porosity and some soil properties such as cation exchange capacity was amended by biochar addition [10] [11]. It caused that the root development and hereby the plant growth was improved when biochar as a soil amendment was applied. As shown in Figure 1(c) and Figure 1(d), the toxic effect of cadmium concentration in the soil on the lavender plant was reduced by the biochar volumetric ratio increased.

The cadmium content in root, stem and leaf tissues were significantly affected by the biochar and cadmium concentration treatments ( $\mathrm{p} \leq 0.01)$. The cadmium content in plant tissues were reduced by biochar application as opposed to a control not receiving biochar (Figure 2(a) and Figure 2(b)). Lavender plant accumulated cadmium in its different tissues from control to the highest cadmium concentration in soil (Figure 2(c) and Figure 2(d)).

The results presented in Figure 3 showed that with receding further from non-biochar treatment (control) to the highest ratio of biochar application a notable trend to reduce the cadmium accumulation by the root, stem and leaf tissues of lavender plant is observed. Biochar application provoked a decrease about $17.5 \%, 43.8 \%$ and $27.0 \%$ in the cadmium content of the root, stem and leaf tissue, respectively at the highest cadmium concentration (Figure 3(a)). In view of the clear differences in the cadmium content in different parts, the decrease of cadmium content was the highest for the stem tissue compared with non-biochar treatment (Figure 3(b)). On the other hand, the biochar addition

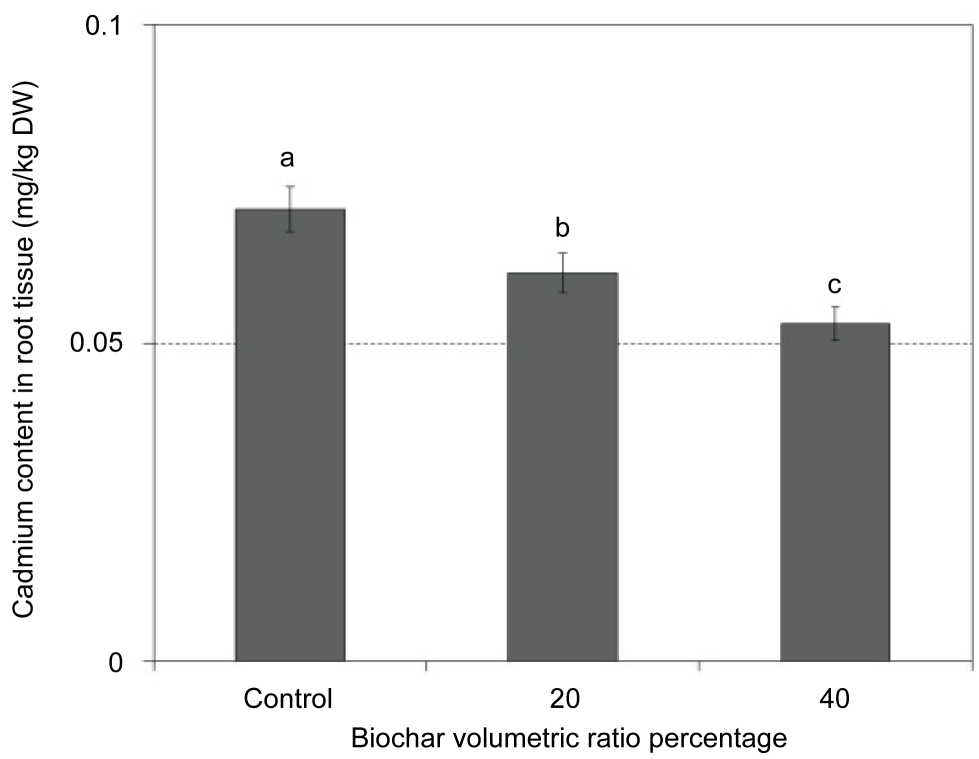

(a) 


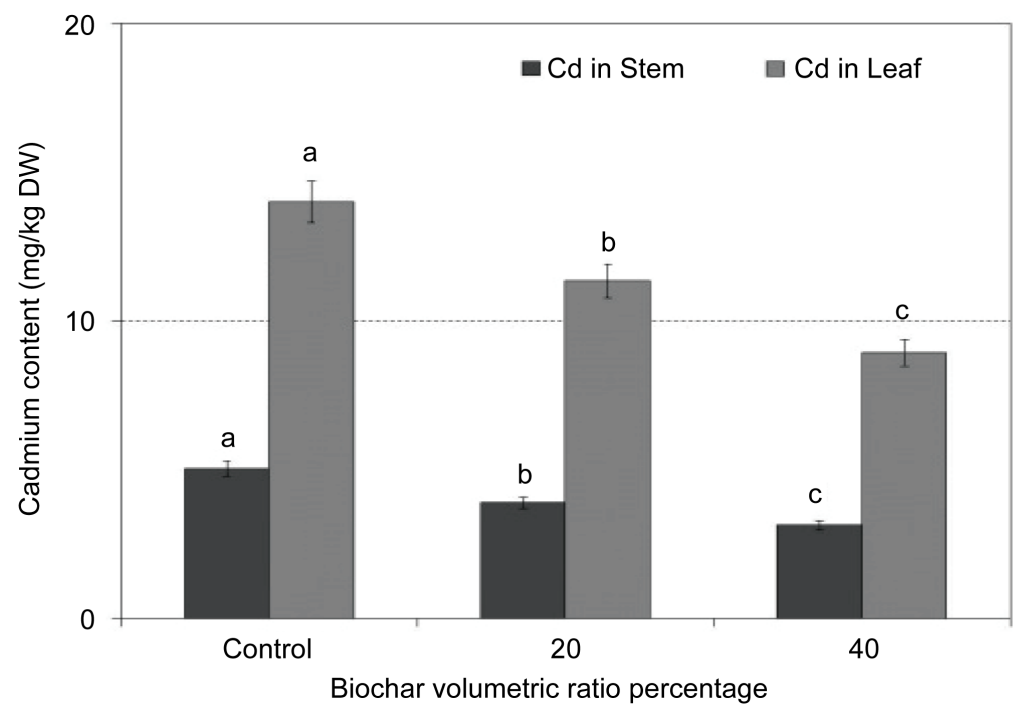

(b)

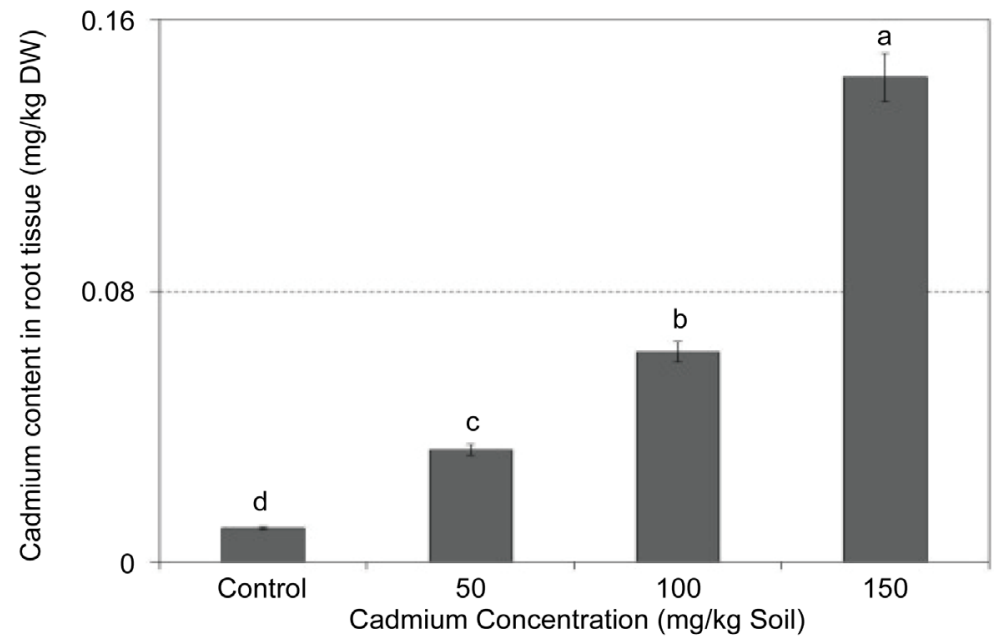

(c)

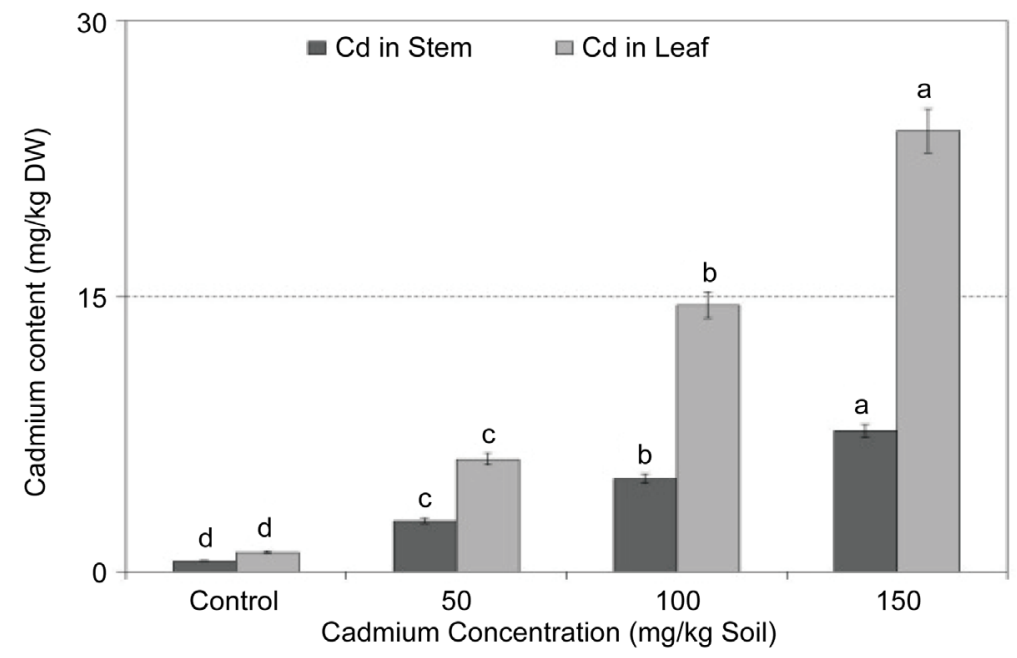

(d)

Figure 2. Effects of biochar (control, 20 and $40 \mathrm{v} / \mathrm{v}$ ) and cadmium concentration (control, 50,100 and $150 \mathrm{mg} \mathrm{Cd} \cdot \mathrm{kg}^{-1}$ soil) on the cadmium accumulation by the lavender plant. Means \pm standard error (S.E.) is shown in error bars $(\mathrm{p} \leq 0.05)$. 


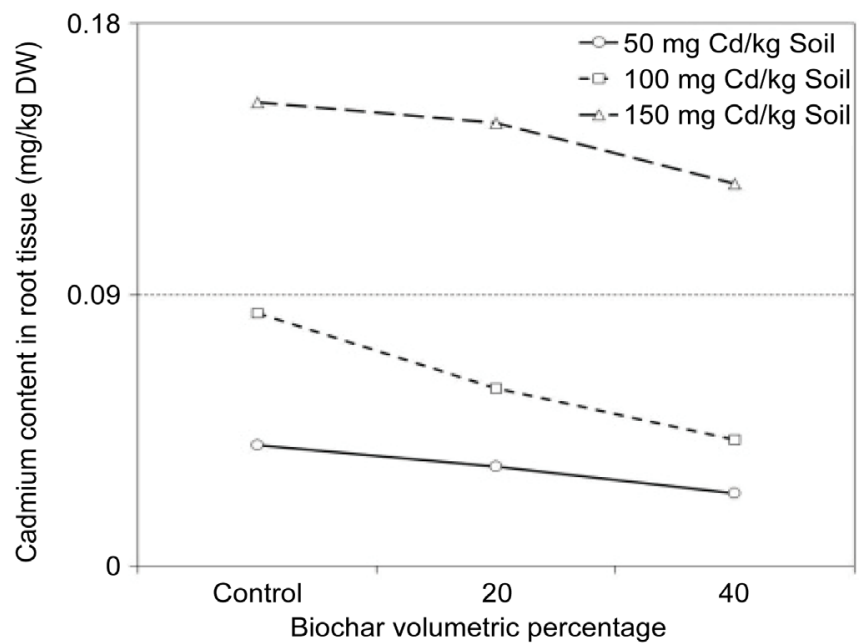

(a)

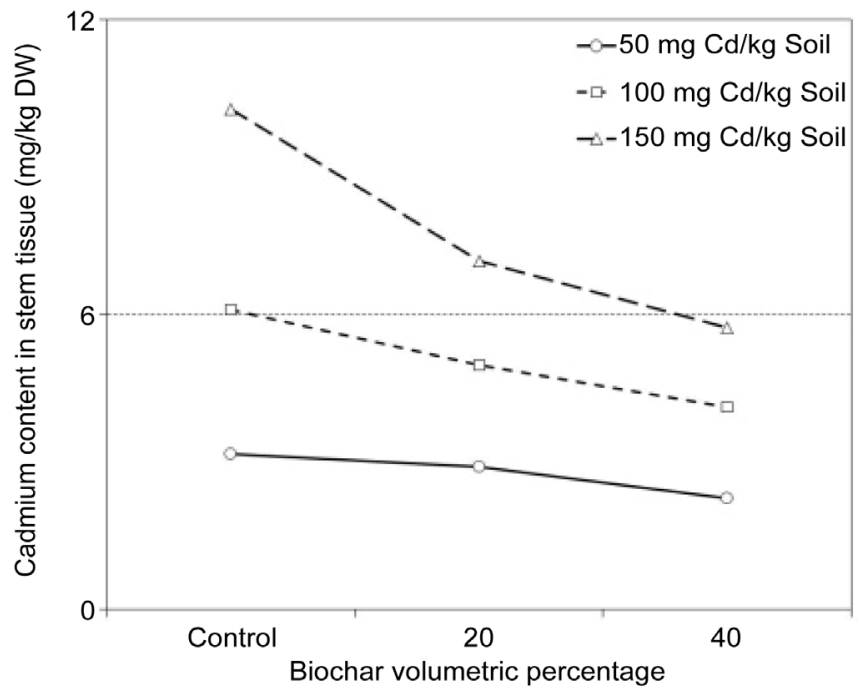

(b)

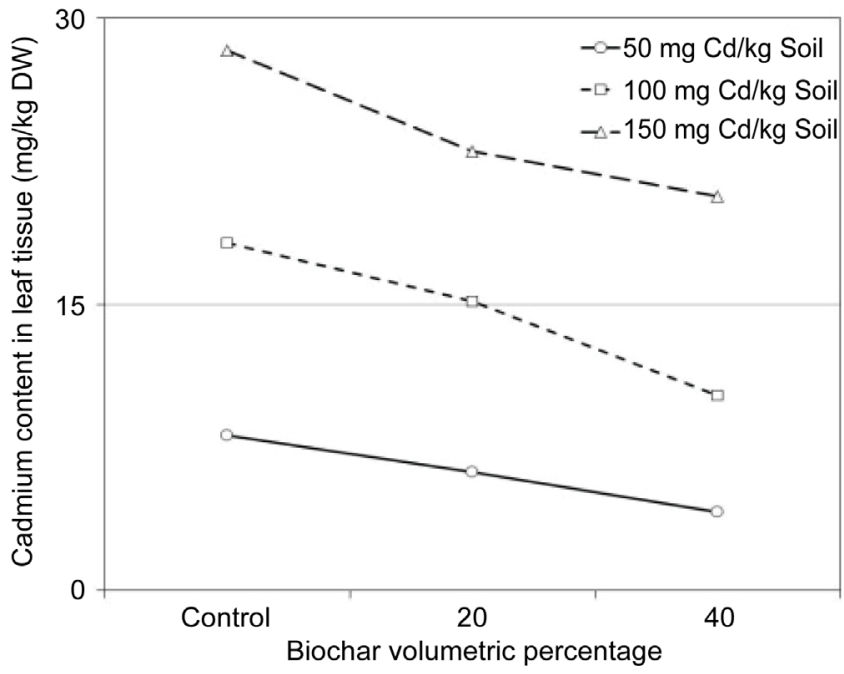

(c)

Figure 3. Interaction effects of biochar (control, 20 and $40 \mathrm{v} / \mathrm{v}$ ) and cadmium concentration (control, 50, 100 and $150 \mathrm{mg} \mathrm{Cd} \cdot \mathrm{kg}^{-1}$ soil) on the cadmium accumulation by the lavender different parts. Means \pm standard error (S.E.) is shown in error bars $(p \leq 0.05)$. 
caused to decrease the cadmium content of the root tissues up to $17.5 \%$ (Figure $3(\mathrm{a}))$.

The effects of biochar and cadmium treatments are presented in Figure 4 . The statistical analysis demonstrated a significant $(\mathrm{p} \leq 0.01)$ decrease in the absorption factor due to addition of biochar. The lowest mean value of absorption factor (0.044) was observed in soils treated with $40 \mathrm{v} / \mathrm{v}$ biochar, the highest value (0.67) was in the control (Figure 4(a)). However there was a significant ( $\mathrm{p} \leq$ 0.01 ) increase in the absorption factor due to the cadmium concentration increase compared to control (Figure 4(b)). The interaction effect of biochar and cadmium concentration revealed that the biochar played an important role to reduce the cadmium content of root tissue and hereby a significant decrease in the absorption factor (Figure 4(c)). Biochar due to its especial properties such as high surface area and cation exchange capacity (CEC) can adsorb the cadmium cation form $\left(\mathrm{Cd}^{2+}\right)$ from soil solution. Many studied reported about strong adsorption affinity of biochar due to high surface area, high cation exchange capacity (CEC) and surface sorption capacity [12]. High cadmium adsorption capacity of biochar caused decrease cadmium available in soil solution thereby the treated soil by biochar $(40 \mathrm{v} / \mathrm{v})$ attributed a significant decrease in the cadmium content of root tissue and then it caused to reduce the absorption factor (AF).

Cadmium as a heavy metal is accumulated in the plant grown on contaminated soils. Mostly, plants accumulate them in the root tissues or the aboveground biomass [13]. Lavender samples of root, stems and leaves were analyzed to assess the issues of accumulation of cadmium in the vegetative organs. The analysis of variance indicated that the cadmium concentration in soil significantly affected the cadmium translocation (TF) from the root to above-ground parts $(\mathrm{p} \leq 0.05)$. In the meantime, the biochar only affected the cadmium absorption (AF) and its effect on translocation factor (both from root to stem and stem to leaves) was not significant. Figure 5(a) showed the cadmium concentration effect on the cadmium translocation from the root to stem of the lavender plant. The results presented in Figure 5(a) revealed a significant decrease in the cadmium translocation from root to stem by increasing cadmium concentration in soil. This research proved that the lavender can accumulate the cadmium in the root tissue. However there was a significant trend to translocate cadmium from stem to leaves when the cadmium concentration in soil increased (Figure 5(b)).

The results demonstrated that the lavender plant as a hyperaccumulator could accumulate cadmium in root tissue and translocate that to stem and leaves but at different patterns. The entry of heavy metals in plants and their accumulation in the tissues of plants depends on the type of plants, contaminants and soil conditions. Heavy metals can be accumulated in different vegetative parts of the plants. The results emphasized that cadmium was accumulated in the aboveground parts of the lavender particularly in the leaf tissues (Figure 5(b)). The outcome was in agreement with Mashhoor Roodi et al., 2012 [2]. 


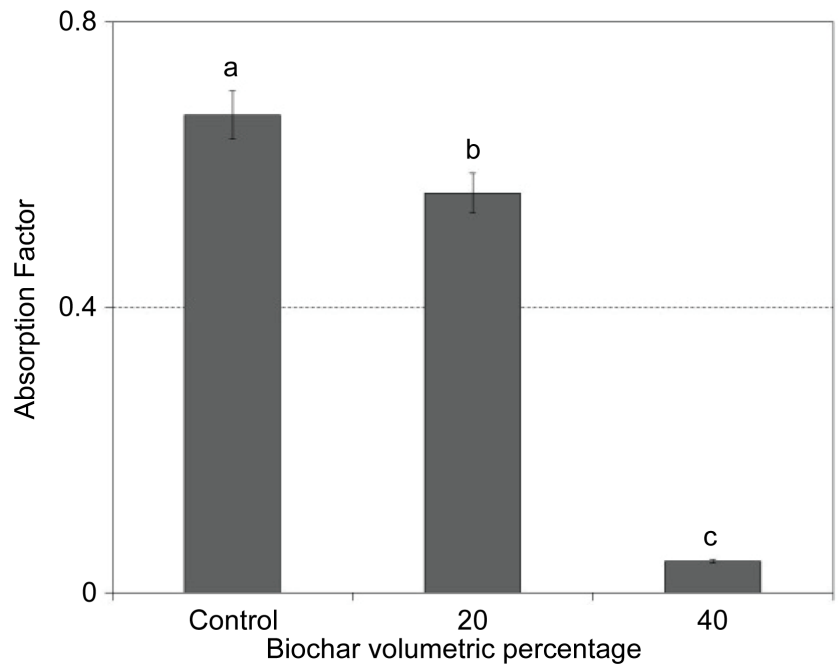

(a)

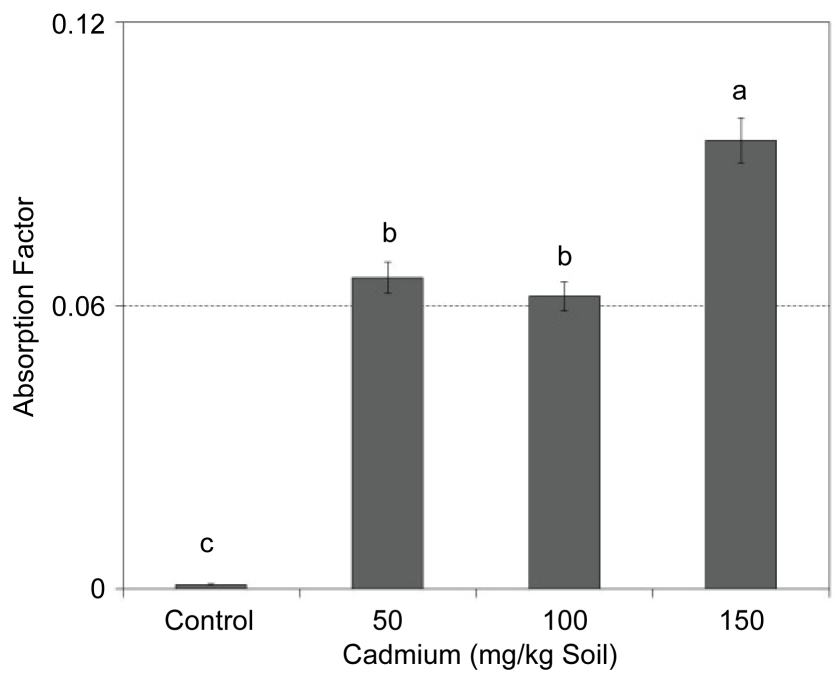

(b)

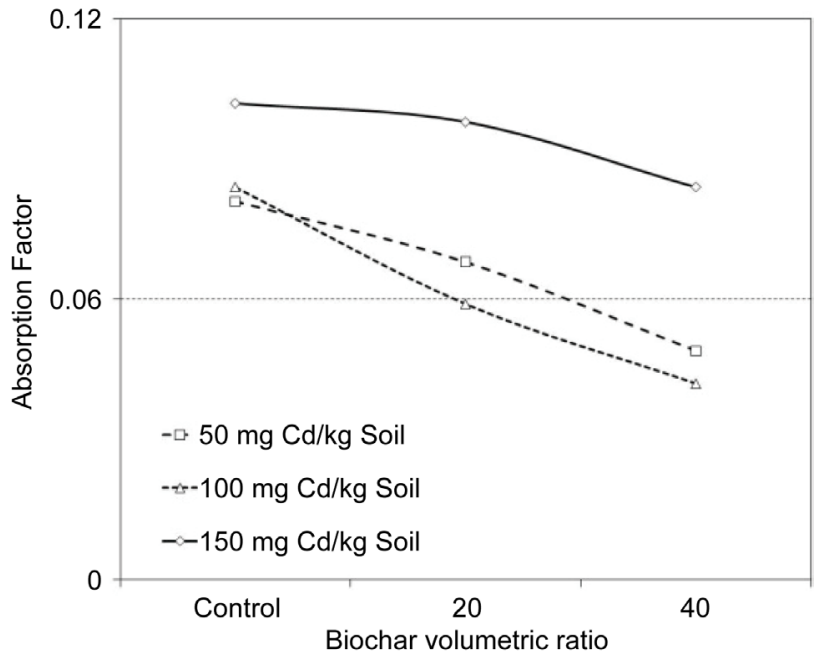

(c)

Figure 4. Simple (a) and (b) and interaction (c) effects of biochar application (control, 20 and $40 \mathrm{v} / \mathrm{v}$ ) and cadmium concentration (control, 50, 100 and $150 \mathrm{mg} \mathrm{Cd} \cdot \mathrm{kg}^{-1}$ soil) on absorption factor (AF). Means \pm standard error (S.E.) is shown in error bars $(p \leq 0.05)$. 


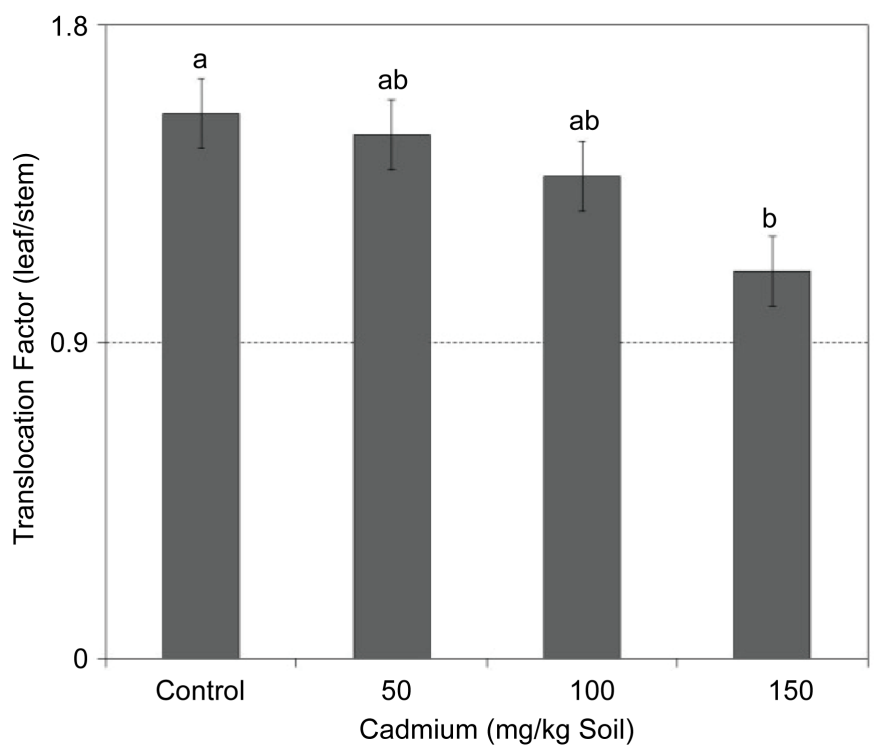

(a)

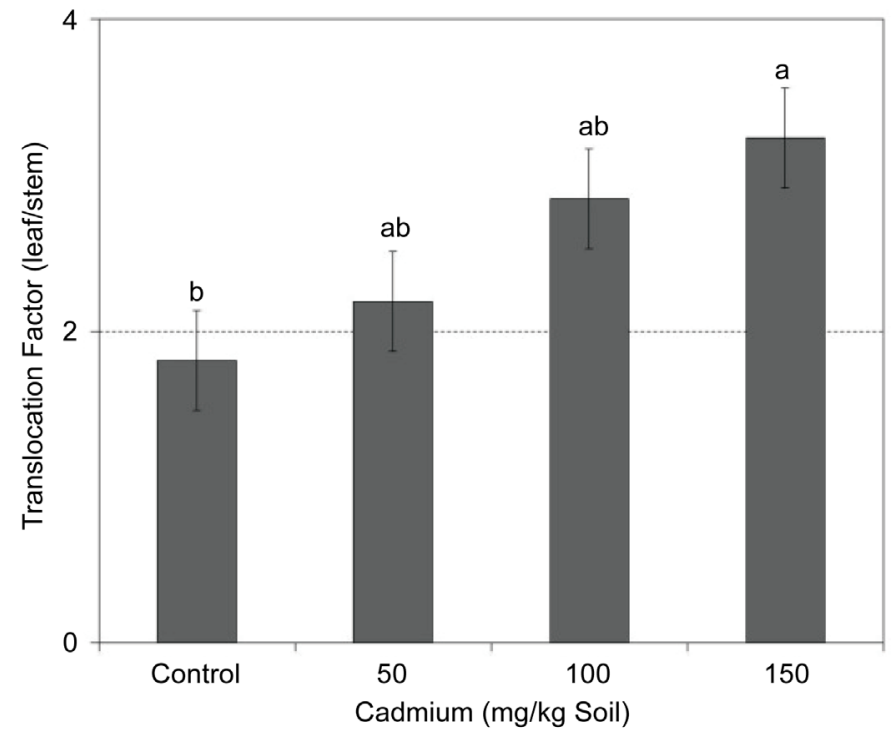

(b)

Figure 5. Effect of cadmium concentration (control, 50, 100 and $150 \mathrm{mg} \mathrm{Cd} \cdot \mathrm{kg}^{-1}$ soil) on translocation factor: (a) from root to stem (stem/root) and (b) from stem to leaf (leaf/ stem). Means \pm standard error (S.E.) is shown in error bars $(\mathrm{p} \leq 0.05)$.

\section{Conclusions}

This study presented that the toxic effect of cadmium concentration in the soil on the lavender plant was reduced by the biochar addition. The results also revealed the biochar effect on cadmium available in the soil solution because the biochar characteristics such as surface area and CEC could improve the soil properties and thereby the lavender plant could withstand the high cadmium concentration by applying biochar. It caused the root development and hereby the plant growth was improved as a result of biochar application as a soil amendment.

High cadmium adsorption capacity of biochar due to its properties caused the 
cadmium available in soil solution; the root cadmium content and then the absorption factor (AF) significantly reduced. The cadmium accumulation in the all lavender plant tissues decreased because the absorption factor was reduced by biochar applied. The translocation factor was increased from the root to the stem and also from the stem to the leaf by the cadmium concentration increased in the soil. It can be concluded that it can be considered the possibility of planting the lavender with biochar application to amend the cadmium polluted soils whereas the accumulation of heavy metals in essential oil of lavender was not observed.

\section{References}

[1] Ayangbenro, A.S. and Oluranti, B.O. (2017) A New Strategy for Heavy Metal Polluted Environments: A Review of Microbial Biosorbents. International Journal of Environmental Research and Public Health, 14.

[2] Mashhoor Roodi, M., Said, Md.A.B.Md. and Honari, H. (2012) Phytoremediation Using the Influence of Aromatic Crop on Heavy-Metal Polluted Soil, a Review. Advances in Environmental Biology, 6, 2663-2668.

[3] Tammeorg, P., Simojoki, A., Makela, P., Stoddard, F.L., Alakukku, L. and Helenius, J. (2013) Biochar Application to a Fertile Sandy Clay Loam in Boreal Conditions: Effects on Soil Proprerties and Yield Formation of Weath, Turnip Rape and Faba Bean. Plant and Soil.

[4] Umeoguaju, F.U. (2009) Conventional and New Ways of Remediating Soils Polluted with Heavy Metals.

Freedman, B. (1995) Enironment Ecology. 2nd Edition, London Academic Press, New York.

[5] Xie, T., Sadasivam, B.Y., Ascesm, Reddy, K.R., Asce, F., Wang, C. and Spokas, K. (2016) Review of the Effects of Biochar Amendment on Soil Properties and Carbon Sequestration. Journal of Hazardous, Toxic, and Radioactive Waste, 20, 1-14. https://doi.org/10.1061/(ASCE)HZ.2153-5515.0000293

[6] Clough, T.J. and Condron, L.M. (2010) Biochar and the Nitrogen Cycle: Introduction. Journal of Environment Quality, 39, 1218-1223. https://doi.org/10.2134/jeq2010.0204

[7] Boline, D.R. and Schrenk, W.G. (1976) A Method for the Determination of Cadmium in Plant Material by Atomic Absorption Spectroscopy. Applied Spectroscopy, 30, 607-610.

[8] Arifin, A., Parisa, A., Hazandy, A.H., Mahmud, T.M., Junejo, N., Fatemeh, A., Mohsen, S., Wasli, M.E. and Majid, N.M. (2012) Evaluation of Cadmium Bioaccumulation and Translocation by Hopeaodorata Grown in a Contaminated Soil. African Journal of Biotechnology, 11, 7472-7482.

[9] Violina, R., Angelova, D.F., Grekov, V.K., Kisyov, K. and Ivanov, I. (2015) Potential of Lavender (Lavandula vera L.) for Phytoremediation of Soils Contaminated with Heavy Metals. International Journal of Biological, Biomolecular, Agricultural, Food and Biotechnological.

[10] Verheijen, F., Jeffery, S., Bastos, A.C., van der Velde, M. and Diafas, I. (2010) Biochar Application to Soils: A Critical Scientific Review of Effects on Soil Properties, Processes and Functions. European Commission, Italy.

[11] Kloss, S., Zehetner, F., Wimmer, B., Buecker, J., Rempt, F. and Soja, G. (2013) Biochar Application to Temperature Soils: Effects on Soil Fertility and Crop Growth 
under Greenhouse Conditions. Journal of Plant Nutrition and Soil Science, 177, 3-15. https://doi.org/10.1002/jpln.201200282

[12] Nigussie, A., Endalkachew, K., Mastawesha, M. and Gebermedihin, A. (2012) Effect of Biochar Application on Soil Properties and Nutrient Uptake of Lettuces (Lactuca sativa) Grown in Chromium Polluted Soils. American-Eurasian Journal of Agriculture \& Environmental Science, 12, 369-376.

[13] Angelova, V.R., Babrikovb, T.D. and Ivanova, K.I. (2009) Bioaccumulation and Distribution of Lead, Zinc, and Cadmium in Crops of Solanaceae Family. Communication of Soil Science and Plant Analysis, 40, 2248-2263.

https://doi.org/10.1080/00103620902961227

Submit or recommend next manuscript to SCIRP and we will provide best service for you:

Accepting pre-submission inquiries through Email, Facebook, LinkedIn, Twitter, etc. A wide selection of journals (inclusive of 9 subjects, more than 200 journals)

Providing 24-hour high-quality service

User-friendly online submission system

Fair and swift peer-review system

Efficient typesetting and proofreading procedure

Display of the result of downloads and visits, as well as the number of cited articles Maximum dissemination of your research work

Submit your manuscript at: http://papersubmission.scirp.org/

Or contact oje@scirp.org 